\title{
Novel BUF2-magnetite nanobioconjugates with cell-penetrating abilities
}

This article was published in the following Dove Press journal: International Journal of Nanomedicine

\author{
Monica Cuellar' \\ Javier Cifuentes' \\ Jessica Perez' \\ Alejandra Suarez-Arnedo' \\ Julian A Serna' \\ Helena Groot ${ }^{2}$ \\ Carolina Muñoz-Camargo' \\ Juan C Cruz' \\ 'Department of Biomedical \\ Engineering, Universidad de los Andes, \\ Bogotá, Colombia; ${ }^{2}$ Human Genetics \\ Laboratory, Department of Biological \\ Sciences, Universidad de los Andes, \\ Bogotá, Colombia
}

\begin{abstract}
Introduction: One of the major challenges of modern pharmacology is the development of systems for the delivery of therapeutic molecules in a controlled and localized manner. One strategy is to use nanostructured supports, which are well suited to carry a large number of molecules on a per mass basis. A major challenge for these supports is, however, their limited ability to bypass the cell membrane. Recent studies propose that to overcome this issue, potent translocating cell-penetrating peptides (CPPs) can be conjugated to their surfaces.
\end{abstract}

Methods: Here, we conjugated the antimicrobial CPP buforin II (BUF2) to the surface of magnetite nanoparticles to enhance their cell penetration. Conjugates were characterized via Fourier transform infrared spectroscopy, dynamic light scattering, and thermogravimetric analysis, and their biocompatibility was corroborated. The conjugates were delivered in both bacterial and mammalian cells demonstrating the intracellular inclusion in THP-1 cells for the first time.

Results: Despite the promising outcome, our studies showed that the obtained conjugates failed to maintain the native antimicrobial activity of BUF2. We hypothesize that to overcome this issue, a flexible linker can be inserted prior to conjugation.

Conclusion: Our study highlights the potential of BUF2-magnetite conjugates as cell-penetrating vehicles for the targeted delivery of pharmacological agents. This provides support for the idea of a promising combined drug delivery and antimicrobial peptide therapy.

Keywords: BUF2-magnetite, antimicrobial activity, cell-penetrating peptides, nanomaterials, drug delivery

\section{Introduction}

Drug delivery systems have attracted considerable attention in the medical arena due to possibilities for treating or eliminating cells of certain diseases in a targeted manner, ie, without affecting the surrounding tissues or cells. Despite their potential, implementation of most drug delivery systems at the clinical level has been largely limited due to challenges such as low membrane permeability and short circulation half-time. ${ }^{1}$ Recent reports suggest that by incorporating cell-penetrating peptides (CPPs) into these systems, these issues can be successfully addressed. This approach takes advantage of CPPs' small size, ease of production, and particularly their ability to spontaneously translocate across the cell membrane or even complex structures such as the blood-brain barrier. ${ }^{1}$

Buforin II (BUF2) is a cationic (+6) and amphipathic 21-residue CPP capable of killing bacteria by efficiently crossing the cell membrane without damaging it and subsequently binding to DNA and RNA, thereby interrupting the replication cycle. ${ }^{2-4}$ The C-terminal region of BUF2 is associated with the antimicrobial mechanism, while a proline hinge in the structure is responsible for aiding the cell membrane penetration without promoting significant disruption. ${ }^{3}$ In spite of its potent antimicrobial activity,
Correspondence: Juan C Cruz;

Carolina Muñoz-Camargo Department of Biomedical Engineering, Universidad de los Andes, Mario Laserna Hall. Cra I Este No 19A-40, Bogotá,

II7II, Colombia

Tel +57 I 3394949 ext 1789, I853

Email jc.cruz@uniandes.edu.co;

c.munoz2016@uniandes.edu.co 
BUF2 is prone to proteolytic degradation by endogenous proteases, which significantly reduces its in vitro and in vivo half-life and consequently its therapeutic value. ${ }^{4-6}$

A strategy to maintain the CPPs biological activities as well as extending their stability, efficacy, and lifespan is the immobilization on nanomaterials. ${ }^{7}$ Immobilization of CPPs on magnetite iron-oxide nanoparticle (MNP) surfaces has been exploited for the development of antibacterial coatings. ${ }^{8}$ Additionally, MNPs have been widely used for a number of biological applications including bioseparations, agents for MRI contrasting, magnetic fluid hyperthermia for cancer treatment, and drug delivery for the treatment of various conditions..$^{9-11}$ MNPs generally exhibit low cytotoxicity depending on factors such as dose, chemical composition, size, structure, surface chemistry, and route of administration. ${ }^{12,13}$ Moreover, they have been extensively used as immobilization supports to improve the stability of a variety of biomolecules including epidermal growth factor, ${ }^{10}$ albumin, ${ }^{14}$ and bacitracin. ${ }^{8}$ Immobilization of biomolecules on MNPs is also advantageous mainly due to the increased number of active molecules per unit mass and the ease of transport and manipulation under magnetic fields. ${ }^{15}$ Accordingly, this work was aimed at exploring the immobilization of BUF2 on magnetite as cell translocating vehicles to enable highly targeted drug delivery applications in mammalian cells. Here, we also worked on estimating possible changes in the antimicrobial activity of BUF2 upon immobilization.

\section{Materials and methods Materials}

Iron (II) chloride tetrahydrate (98\%) and sodium hydroxide $(\mathrm{NaOH})(98 \%)$ were obtained from PanReac AppliChem. Iron (III) chloride hexahydrate (97\%), dimethyl sulfoxide (99.5\%), tetramethylammonium hydroxide (TMAH) (25\%), (3-aminopropyl) triethoxysilane (APTES) (98\%), carboxymethyl cellulose (CMC) (98\%), N-[3-(dimethylamino)propyl]-N'-ethylcarbodiimide hydrochloride (EDC) (98\%), and glutaraldehyde (25\%) were purchased from Sigma-Aldrich Co. DMEM, RPMI 1640 medium, FBS, and trypsin EDTA were obtained from Biowest. Penicillin/ streptomycin (P/S) was purchased from Lonza. BUF2 (BUF2-TRSSRAGLQFPVGRVHRLLRK) and fluorescein isothiocyanate (FITC)-BUF2 were synthetized by the Peptide Synthesis Facility at Pompeu Fabra University and GL Biochem (Shanghai, China). Purification was performed by high-pressure liquid chromatography $(>95 \%)$, and masses were confirmed via mass spectrometry as we did in a previous work. ${ }^{4}$ Vero Cells (ATCC ${ }^{\circledR}$ CCL-81), THP-1 Cells (ATCC ${ }^{\circledR}$
TIB-202) were used for citotoxicity and delivery assays. Bacterial strain used was Escherichia coli (ATCC 25922).

\section{Synthesis and functionalization of magnetite nanoparticles}

Nanoparticles were obtained by co-precipitating $500 \mathrm{mM}$ ferric chloride and $250 \mathrm{mM}$ ferrous chloride (molar ratio 1:2) in the presence of a $5 \mathrm{M} \mathrm{NaOH}$ aqueous solution at $90^{\circ} \mathrm{C}$. The solution was left to cool for at least 30 minutes prior to use. Nanoparticles were subsequently washed with distilled water to remove excess reagents aided by a permanent magnet. The MNP suspension (100 mg) was adjusted to $\mathrm{pH}$ 11.3 and sonicated for 10 minutes. TMAH solution $(2 \mathrm{~mL}$, $25 \%(\mathrm{v} / \mathrm{v}))$ was then added to the magnetite solution and sonicated for 10 minutes. APTES $(200 \mu \mathrm{L})$ was added to the magnetite solution for silanization along with $100 \mu \mathrm{L}$ of acetic acid. Silanized nanoparticles were washed five times with milli Q water to remove excess of APTES aided by a strong permanent magnet and subsequently resuspended in $30 \mathrm{~mL}$ of milli Q water. Silanization rendered free amine groups on the surface of the nanoparticles to subsequently conjugate the N-terminal and C-Terminal of BUF2 to the nanoparticles. Free amine groups were also used to conjugate Phalloidin Alexa Fluor 488 via glutaraldehyde as crosslinker (see the following section for details on the conjugation protocol).

\section{Nanoparticle characterization}

Nanoparticle size was confirmed by dynamic light scattering (DLS, Zeta-Sizer Nano-ZS; Malvern Instruments, Malvern, UK), and the sample was sonicated for 6 hours in water at $37^{\circ} \mathrm{C}$. Surface modifications of MNPs with APTES and BUF2 were confirmed via Fourier transform infrared spectroscopy (FTIR) using a Bruker Alpha II FTIR Eco-ATR (Bruker Optik GmbH, Ettlingen, Germany). Spectra were collected in the range of 4,000-400 $\mathrm{cm}^{-1}$ with a spectral resolution of $2 \mathrm{~cm}^{-1}$. Thermogravimetric analysis (TGA) was carried out with $10 \mathrm{mg}$ of samples in a simultaneous TGA/differential scanning calorimetry (TA Instruments, Newcastle, DE, USA). Analyses were performed by ramping up the temperature at a rate of $10^{\circ} \mathrm{C} / \mathrm{min}$ from $25^{\circ} \mathrm{C}$ to $800^{\circ} \mathrm{C}$ in a nitrogen atmosphere with a gas flow rate of $100 \mathrm{~mL} / \mathrm{min}$. TGA data are shown as the percentage of mass loss as a function of temperature.

\section{In silico analysis of BUF2 in vitro and in vivo half-life}

A prediction of BUF2 stability and half-life in vivo and in vitro was completed in silico via the Antimicrobial Peptide 
Database (http://aps.unmc.edu/AP/main.php). ProtParam tool relies on the "N-end rule", which relates the half-life of a protein to the identity of its $\mathrm{N}$-terminal residue. ${ }^{16}$

\section{Conjugation of BUF2 on magnetite nanoparticles}

To obtain BUF2-magnetite conjugates (Figure 1A), $100 \mathrm{mg}$ of magnetite-APTES nanoparticles were freeze dried for 24 hours and subsequently dispersed in $30 \mathrm{~mL}$ of distilled water and sonicated for 30 minutes. This was followed by addition of $1 \mathrm{~mL}$ of glutaraldehyde $2 \%(\mathrm{v} / \mathrm{v})$. The reaction mixture was left at rest for 30 minutes. Excess of glutaraldehyde was removed by washing the nanoparticles five times with milli $Q$ water with the aid of a strong permanent magnet. Finally, $500 \mu \mathrm{L}$ of BUF2 solution at $1 \mathrm{mg} / \mathrm{mL}$ in sterile PBS $1 \mathrm{X}$ was added to the nanoparticles solution and left to react overnight. This solution was then washed four times with distilled water and freeze dried for 24 hours. Alternatively, BUF2-FITC-magnetite conjugates were prepared by conjugation to the $\mathrm{C}$-terminal with the aid of 2 equivalents of EDC and $\mathrm{N}$-hydroxysuccinimide with respect to the free amine groups on the surface of the nanoparticle. The reaction was conducted under continuous agitation at room temperature for 24 hours on $100 \mathrm{mg}$ of well suspended magnetite-APTES nanoparticles in distilled water. After conjugation, samples were thoroughly washed with milli Q water with the aid of a strong permanent magnet.

\section{Cell culture and cytotoxicity assay}

The African green monkey fibroblast-like kidney cells (Vero ATCC CCL-81), their maintenance, and subculture were described in a previous work. ${ }^{4}$ Cell monolayers were trypsinized, washed with culture medium, and plated in a flat-bottomed 96-well microtiter plate with $3 \times 10^{4}$ cells per well, and then cell toxicity was determined by lactate dehydrogenase (LDH) assay kit (Thermo Fisher Scientific, Waltham, MA, USA). Vero cells were exposed to magnetite and BUF2-magnetite conjugates in serially diluted samples starting at $100 \mu \mathrm{g} / \mathrm{mL}$ down to $6.25 \mu \mathrm{g} / \mathrm{mL}$ during 24 and 72 hours of incubation at $37^{\circ} \mathrm{C}$ and $5 \% \mathrm{CO}_{2}$. Cells without treatment were used as a negative control, and for the positive control, cells were treated with LDH 10X lysis buffer.
A
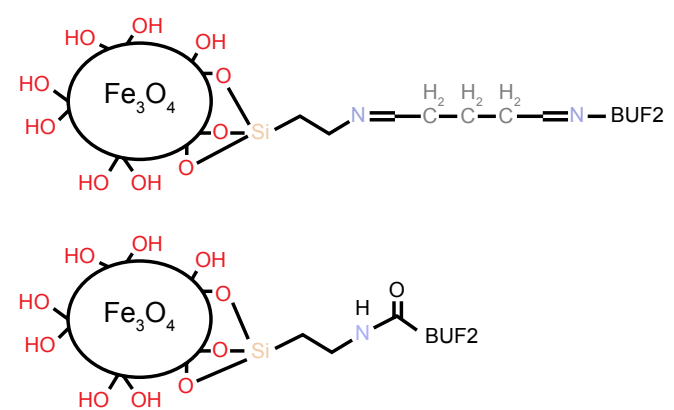

C

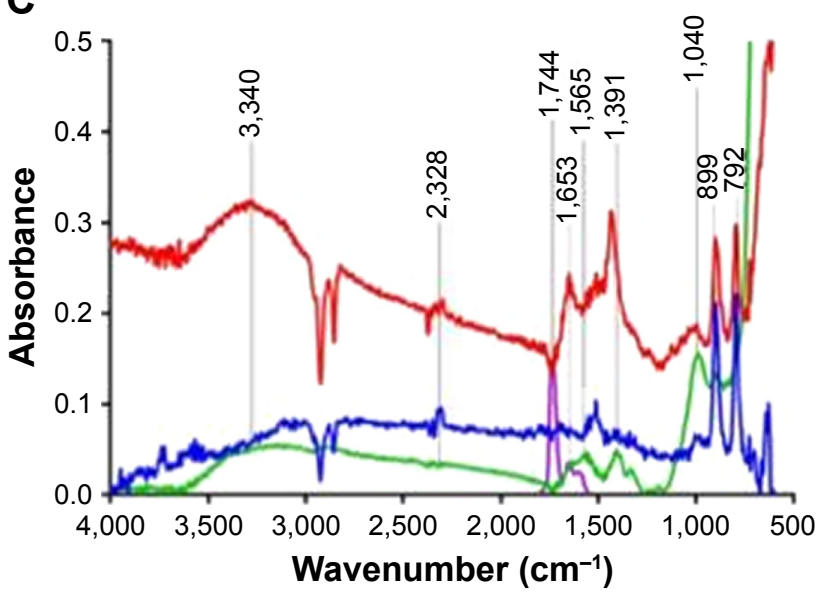

B

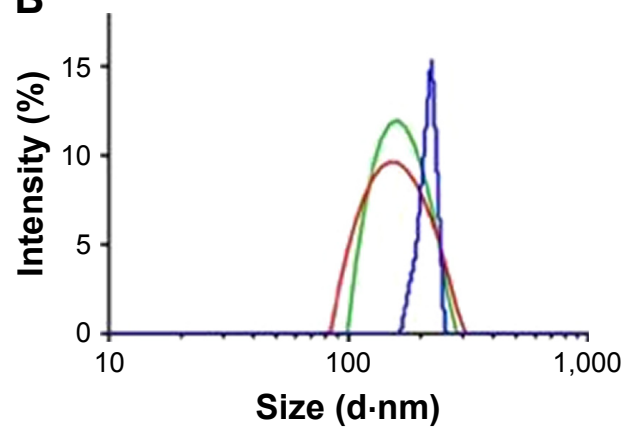

D

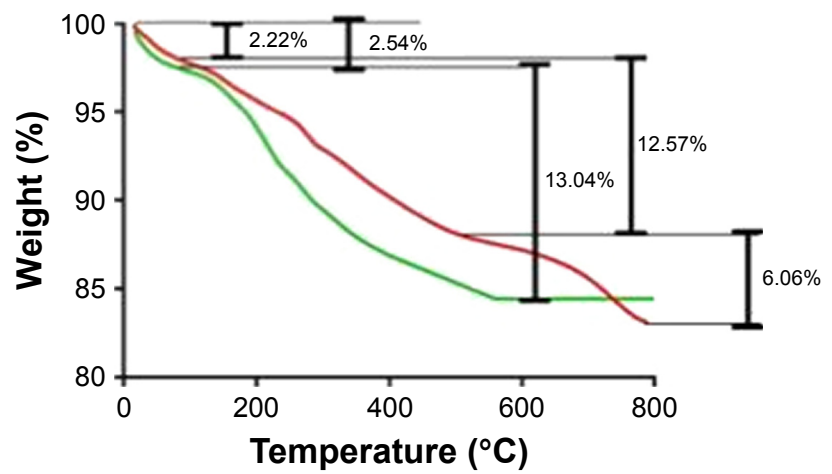

Figure I (A) Schematic of the BUF2-magnetite by conjugation with glutaraldehyde (top) and EDC (bottom) as crosslinkers. (B) DLS histograms for size distribution of magnetite nanoparticles at different functionalization steps. Bare magnetite (red), magnetite functionalized with APTES (green), and magnetite conjugated with BUF2 (blue). (C) FTIR spectra of magnetite (blue), magnetite with APTES (red), BUF2 (purple), and magnetite-APTES-BUF2 (green). (D) TGA of magnetite (green) and magnetite conjugated with BUF2 (red). The first weight loss steps (2.54\% and 2.22\%) represent the dehydration of the samples. Second weight loss steps (I2.57\% and I3.04\%) correspond to physically absorbed organic solvents. The final weight loss step (6.06\%) is attributed to the detachment of BUF 2 from the nanoparticle's surface.

Abbreviations: BUF2, buforin II; EDC, N-[3-(dimethylamino)-propyl]-N'-ethylcarbodiimide hydrochloride; DLS, dynamic light scattering; APTES, (3-aminopropyl) triethoxysilane; FTIR, Fourier transform infrared spectroscopy; TGA, thermogravimetric analysis. 
After incubation, plates were centrifuged at $300 \times g$ for 5 minutes, and the supernatant was transferred to a new plate followed by addition of $50 \mu \mathrm{L}$ of LDH reaction mixture during 30 minutes. The absorbance from the $\mathrm{LDH}$ released was quantified at $490 \mathrm{~nm}$ wavelength and $650 \mathrm{~nm}$ as reference wavelength, using a microplate reader. Cell viability was calculated by triplicate readings as the mean absorbance of LDH activity by the following formula: $\%$ Cell viability = $\left(\mathrm{M}_{\text {sample }}-\mathrm{M}_{\text {ncontrol }}\right) /\left(\mathrm{M}_{\text {pcontrol }}-\mathrm{M}_{\text {ncontrol }}\right) \times 100$.

\section{Antimicrobial activity assay}

Antimicrobial activity of conjugates and peptide was determined by the broth microdilution assay, as described by Park et al. ${ }^{3}$ Two concentrations of each BUF2-magnetite (500 and $100 \mu \mathrm{g} / \mathrm{mL}$ ) treatment were assayed against E. coli (ATCC 25922), as well as two concentrations of BUF2 (100 and $3.125 \mu \mathrm{M})$. Bacterial cells were also treated with a negative (no treatment) and a positive control (10 $\mu \mathrm{M}$ gentamicin). Fifty microliters of each treatment was seeded in triplicate on a 96-well flat bottom microplate (TPP). Bacterial cells were cultured overnight in LB Broth at $37^{\circ} \mathrm{C}$, and an aliquot of this culture was taken and incubated in fresh medium until mid-logarithmic phase was achieved. Cells were harvested by centrifugation, washed three times with a $10 \mathrm{mM}$ sodium phosphate buffer ( $\mathrm{pH} 7.4)$, and diluted 1:10,000 in the same buffer. Fifty microliters of the diluted cell suspension was added to $50 \mu \mathrm{L}$ of each of the treatments assayed and incubated for 3 hours at $37^{\circ} \mathrm{C}$. After incubating the mixture, 100 $\mu \mathrm{L}$ of fresh $\mathrm{LB}$ Broth was added to each well and incubated for 16 more hours at $37^{\circ} \mathrm{C}$. Inhibitory growth effects were determined by absorbance at $620 \mathrm{~nm}$. The presence of $\mathrm{NaCl}$ and $\mathrm{CMC}$ on the antimicrobial activity of the peptide and conjugates was also assayed.

\section{Hemolysis assay}

Blood was obtained from a healthy donor in a vacutainer blood tube with EDTA. The hemolytic activities of magnetite and BUF2-magnetite conjugates were evaluated according to a method described previously. ${ }^{4}$ Serially diluted concentrations of magnetite and BUF2-magnetite conjugates were prepared for the test in concentrations ranging from $1,500 \mu \mathrm{g} / \mathrm{mL}$ to $2.93 \mu \mathrm{g} / \mathrm{mL}$. The hemolytic assay was performed in a 96-well microtiter plate; $100 \mu \mathrm{L}$ of either magnetite or BUF2-magnetite and $100 \mu \mathrm{L}$ of the diluted red blood cells were incubated for 1 hour at $37^{\circ} \mathrm{C}$. The positive control was an erythrocyte suspension incubated with ultrapure water $(100 \%$ hemolysis), and the negative control was an erythrocyte suspension incubated with PBS 1X ( $0 \%$ hemolysis).

\section{Delivery of BUF2-magnetite conjugates in mammalian cells and E. coli}

Translocation of conjugates and peptide in mammalian cells and bacteria was imaged via confocal microscopy. Briefly, fluorescently labeled BUF2 (BUF2-FITC) was conjugated to magnetite as described earlier using both glutaraldehyde and EDC as crosslinkers. BUF2-FITC and BUF2-FITC-magnetite conjugates were then delivered to THP-1 cells at a dilution ratio of 1:100 in $1 \mathrm{~mL}$ of RPMI $(10 \% \mathrm{FBS}$ and $1 \% \mathrm{P} / \mathrm{S})$. Samples were incubated for 1 hour at $37^{\circ} \mathrm{C}$ and $5 \% \mathrm{CO}_{2}$. Also, BUF2-FITC was delivered to E. coli (0.5 McFarland standard) at a dilution ratio of 1:100 in $1 \mathrm{~mL}$ of PBS 1X. Samples were incubated for 1 hour at room temperature. Imaging was conducted in a confocal laser scanning microscope Olympus FV1000 with a 60x/NA 1.35 oil immersion objective. Finally, image analysis was performed in ImageJ and Fiji.

\section{Results and discussion Nanoparticle characterization}

Size distribution of MNPs after each functionalization step was determined by DLS of samples suspended in distilled water at $1 \mathrm{mg} / \mathrm{mL}$. Figure $1 \mathrm{~B}$ shows that the size distribution by intensity increases after each functionalization step. Bare MNPs exhibited a mean hydrodynamic diameter of $161 \mathrm{~nm}$ with a polydispersity index (PI) of $14.66 \%$. After silanization, the mean hydrodynamic diameter increased to $170 \mathrm{~nm}$ with a PI of $23.08 \%$. Finally, conjugation of BUF 2 led to a mean hydrodynamic diameter of $213.5 \mathrm{~nm}$ and a PI of $12.48 \%$. The sizes and PIs obtained here are comparable with those reported elsewhere for the same synthesis method. ${ }^{17,18}$

Surface modifications of MNPs were confirmed and shown in Figures $1 \mathrm{C}$ and D by FTIR and TGA. Figure 1C shows the FTIR spectra of bare, and APTES- and BUF2conjugated MNPs. FTIR spectrum of bare nanoparticles exhibited absorption bands at around 632 and $585 \mathrm{~cm}^{-1}$, which can be attributed to the $\mathrm{Fe}-\mathrm{O}$ bond of iron oxide. ${ }^{16,19}$ Silanization with APTES was confirmed by the presence of the $\mathrm{Si}-\mathrm{O}$ stretching vibration at about $1,040 \mathrm{~cm}^{-1}$ as well as bands at 1,391 and $1,653 \mathrm{~cm}^{-1}$, which can be explained by bending vibrations of $\mathrm{C}-\mathrm{H}$ and $\mathrm{N}-\mathrm{H}$, respectively. ${ }^{20}$ Finally, conjugation of BUF2 was verified by the presence of the amide I band at $1,650 \mathrm{~cm}^{-1}$ and $\mathrm{NH}$ and $\mathrm{CN}$ stretching vibrations of the peptide at $1,565 \mathrm{~cm}^{-1} .{ }^{20}$

The presence of BUF2 conjugates on the surface of the MNPs was also assessed via TGA (Figure 1D). Magnetite and BUF2-magnetite conjugates showed a first weight loss of $2.54 \%$ and $2.22 \%$ due to the dehydration of the samples. 
Table I APD in silico stability and half-life of the BUF2 peptide

\begin{tabular}{|c|c|c|c|c|}
\hline \multirow{3}{*}{\multicolumn{2}{|c|}{ Instability index }} & \multicolumn{3}{|l|}{ Half-life } \\
\hline & & \multirow{2}{*}{$\begin{array}{l}\text { In vitro } \\
\text { Mammalian } \\
\text { reticulocytes }\end{array}$} & \multicolumn{2}{|l|}{ In vivo } \\
\hline & & & Yeast & E. coli \\
\hline 84.2 & Unstable & 7.2 hours & $>20$ hours & $>10$ hours \\
\hline
\end{tabular}

Abbreviations: APD, Antimicrobial Peptide Database; E. coli, Escherichia coli.

Second weight loss for bare magnetite approached $13.04 \%$, while for the BUF2-magnetite conjugates was of $12.57 \%$. These losses can be attributed to physically absorbed organic compounds left by the synthesis and functionalization processes. Finally, the detachment of BUF2 from the magnetite is estimated with the final weight loss step $(6.06 \%)$. This roughly corresponds to $3 \times 10^{5}$ BUF2 molecules/MNP.

\section{In silico analysis of BUF2}

Table 1 summarizes the in silico stability and half-life in vitro and in vivo of BUF2 as predicted by the Antimicrobial Peptide Database. In this case, the instability index estimates the stability of peptide molecules in a test tube (reference value of 40 for stable molecule). For BUF2, the index was 84.20 , which indicates low stability and thereby the necessity of finding a method to increase BUF2 stability without detrimentally impacting its antimicrobial capacities. ${ }^{21}$ In contrast, half-life is a prediction of the time it takes for half of the amount of protein/peptide in a cell to disappear after its synthesis in the cell. This parameter is related with the N-end rule originated from the observations that the identity of the $\mathrm{N}$-terminal residue of a protein plays an important role in determining its stability in vivo. ${ }^{22}$ In this regard, the predicted half-life indicates a short life while it is tested in vitro, while its in vivo half-life is greater than 10 hours.

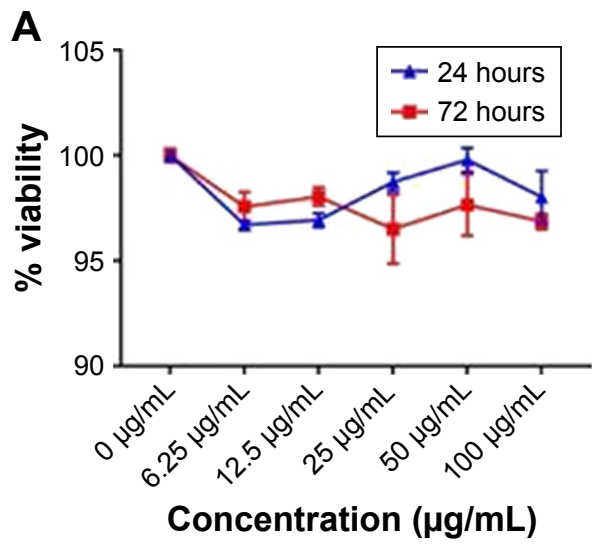

Figure 2 (Continued)

\section{Biocompatibility and cellular delivery of BUF2-magnetite conjugate}

In accordance with the ISO 10993 standard about biocompatibility of nanomaterials, we assessed the cytotoxic (100-6.25 $\mu \mathrm{g} / \mathrm{mL}$ ) effect on Vero cells (ATCC ${ }^{\circledR}$ CCL-81) and hemolytic effect in red blood cells $(1,500-2.93 \mu \mathrm{g} / \mathrm{mL})$ of the BUF2-magnetite conjugate (Figure 2A and B). The results showed that the viability of Vero cells exceeded $95 \%$ in the presence of BUF2-magnetite conjugate for all evaluated concentrations. Similarly, hemolysis levels remained below $5 \%$, which complied with the followed ISO standard. The well documented antimicrobial activity of BUF2 includes a translocation step across bacterial membranes without promoting disruption. ${ }^{23}$ Here, we explored whether this translocation ability is preserved after immobilization by exposing THP-1 cells to the BUF2-magnetite conjugate. Our confocal images corroborated for the first time, to the best of our knowledge, that BUF2-FITC-magnetite conjugates are capable of translocating the membrane of THP-1 cells without significantly reducing their viability (Figure 2C and D). This is in contrast with the bare MNPs that failed to translocate (Figure 2E) and the peptide alone that remains in THP-1 cell membrane (Figure 2F). We also confirmed the entrance of our conjugate into E. coli (Figure 2G).

\section{Antimicrobial activity}

Preliminary results showed that as opposed to BUF2, BUF2-magnetite conjugates failed to produce any significant antimicrobial activity. This was the case for conjugates prepared with both EDC (MBE) and glutaraldehyde (MBA) as crosslinkers (Figure 3A and B). In an effort to understand the possible causes for this result, we conducted variations in the components of the growth medium. We first

B

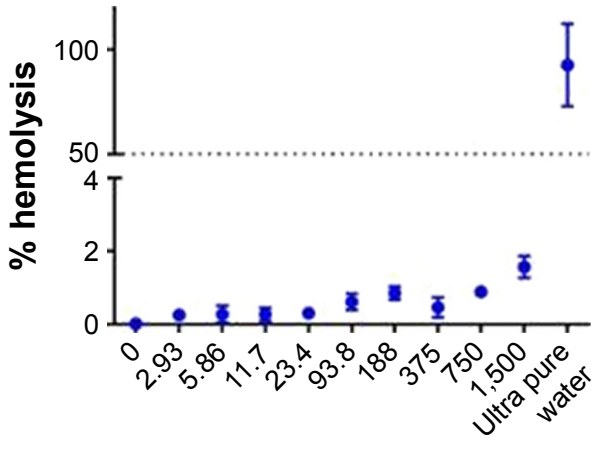

Concentration $(\mu \mathrm{g} / \mathrm{mL})$ 

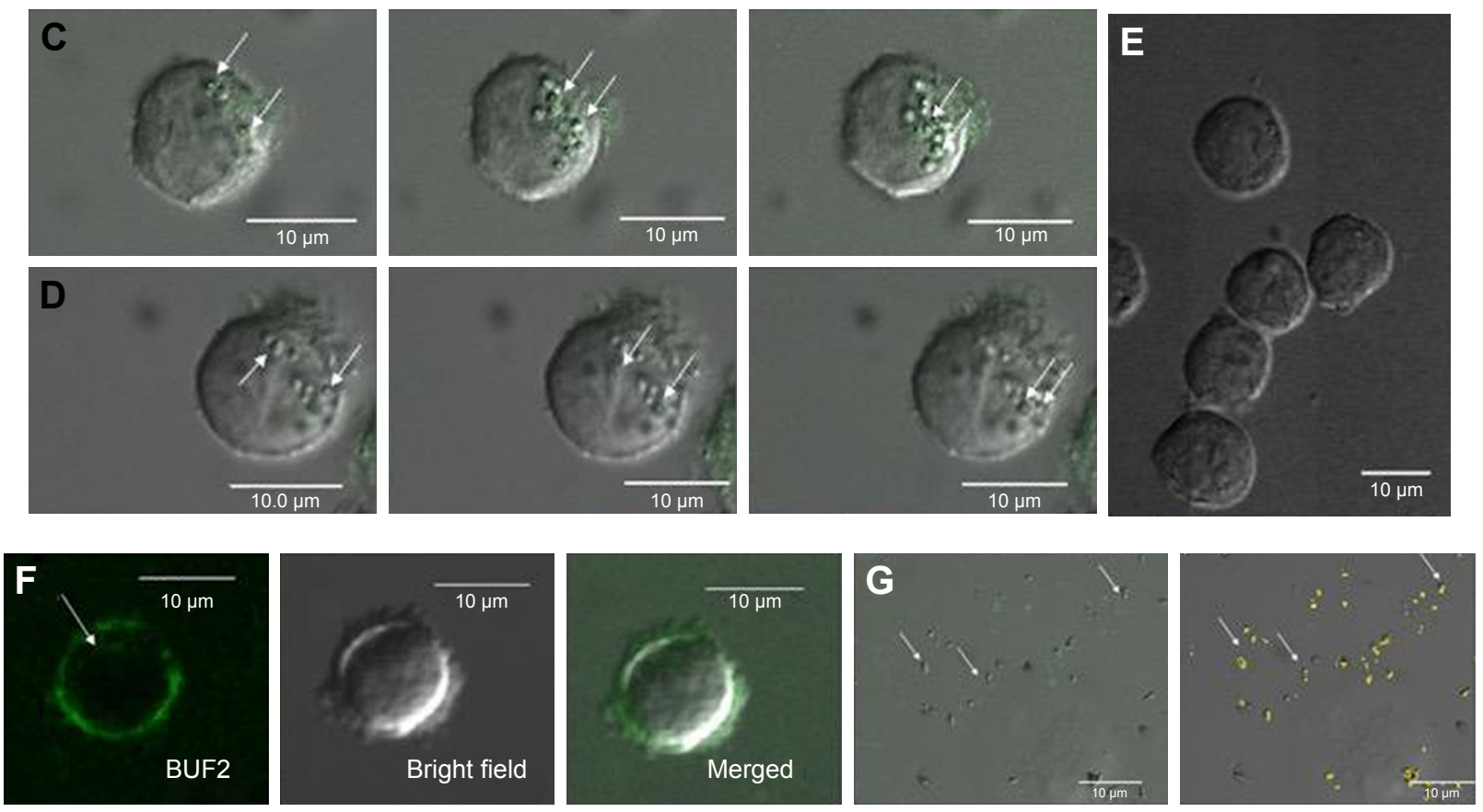

Figure 2 (A) Cytotoxicity of BUF2-magnetite conjugates as tested by LDH assays after 24 and 72 hours. Cell viability remained above $95 \%$ for all studied concentrations. (B) Assessment of the hemolytic effect of BUF2-magnetite conjugates at different concentrations. Data points are mean data of each concentration. In all cases, hemolysis was below 5\%. (C) Confocal microscopic images of effective cellular internalization (THP-I cells) of BUF2-FITC-magnetite as prepared by conjugation via glutaraldehyde (arrow in inset). Scale bar corresponds to $10 \mu \mathrm{m}$. (D) Confocal microscopic images of effective cellular internalization (THP-I cells) of BUF2-FITC-magnetite as prepared by conjugation via EDC (arrow in inset). Scale bar corresponds to $10 \mu \mathrm{m}$. (E) Confocal microscopic image showing failed internalization of fluorescently labeled bare magnetite (negative control). (F) Confocal microscopic images of effective cellular internalization of BUF2-FITC (arrow in inset). Scale bar corresponds to I0 $\mu$ m. (G) Confocal microscopic images of internalization of BUF2-FITC into E. coli (arrow in inset). The image on the right shows the threshold mask to BUF2-FITC to remove the fluorescence background. Scale bar corresponds to $10 \mu \mathrm{m}$.

Abbreviations: BUF2, buforin II; LDH, lactate dehydrogenase; EDC, N-[3-(dimethylamino)-propyl]-N'-ethylcarbodiimide hydrochloride; FITC, fluorescein isothiocyanate; E. coli, Escherichia coli.

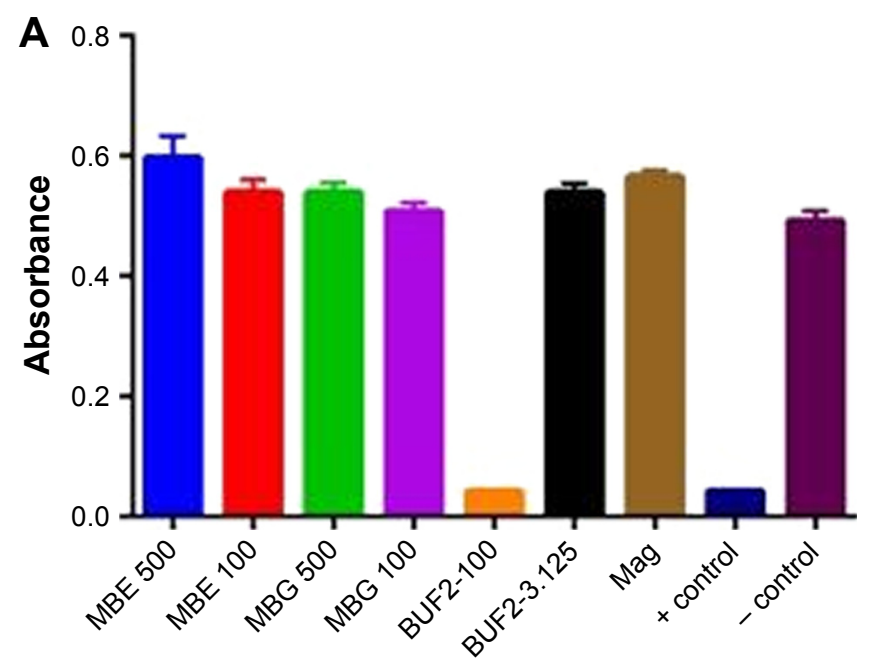

B

\section{Treatment}

Figure 3 (A) Antimicrobial activity against Escherichia coli of magnetite (brown) and BUF2-magnetite $(500 \mu \mathrm{g} / \mathrm{mL}$, green; $100 \mu \mathrm{g} / \mathrm{mL}$, purple) as prepared by conjugation via glutaraldehyde. BUF2-magnetite as prepared by conjugation via EDC at the same concentrations (blue and red, respectively). Comparison with the antimicrobial activity of BUF2 at $100 \mu \mathrm{M}$ (orange) and $3.125 \mu \mathrm{M}$ (black). The positive control was Escherichia coli in gentamicin at $10 \mu \mathrm{M}$, and suspension containing only cells was the negative control. (B) Actual image of the microplate where the antimicrobial assay was conducted. BUF2 at $100 \mu \mathrm{M}$ and the positive control showed insignificant turbidity when compared with the rest of the treatments.

Abbreviations: BUF2, buforin II; EDC, N-[3-(dimethylamino)-propyl]-N'-ethylcarbodiimide hydrochloride; Mag, magnetite; MBE, BUF2-magnetite conjugated with EDC; MBG, BUF2-magnetite conjugated with glutaraldehyde. 
started by carrying out the tests in the presence of $0.1 \mathrm{M} \mathrm{NaCl}$, which showed BUF2 inhibition and no impact for the conjugates, (data not shown). Next set of experiments responded to the notion that conjugates were not fully suspended in the medium during the test. Accordingly, CMC was added to the medium to increase its viscosity and maintain the conjugates suspended throughout the experiment. No inhibitory bacterial growth effect was observed in the presence of CMC for the conjugates, and a complete loss of activity was detected for BUF2 (data not shown). This was attributed to interactions of BUF2 with a charged moiety present in the CMC structure. Magnetite alone showed no antimicrobial or growth promoting activity. Taken all together, our findings suggest that upon immobilization, regions of BUF2 responsible for interaction with the replication machinery of $E$. coli were blocked, which led to a total loss of the antimicrobial functionality. A possible avenue to overcome this issue is to conjugate the peptide with the aid of a flexible spacer that helps to maintain the structural integrity.

\section{Conclusion}

We presented a feasible approach for immobilization of BUF2 on MNPs. Upon immobilization, BUF2 loses antimicrobial activity most likely due to the blockage of C-terminal residues involved in abrogating the replication machinery of E. coli. BUF2-magnetite conjugates are still capable of bypassing mammalian and bacterial membranes very effectively without promoting disruption as evidenced by the high biocompatibility of LDH assays. Our study highlights the potential of BUF2-magnetite conjugates as cell-penetrating vehicles for the targeted delivery of pharmacological agents. This provides support for the idea of a promising combined drug delivery and antimicrobial peptide therapy.

\section{Acknowledgments}

This research was funded by the Department of Biomedical Engineering and by the Fondo de Apoyo a Profesores Asistentes (Research Support Fund for Assistant Professors [FAPA] to Carolina Muñoz and Juan Carlos Cruz), Universidad de Los Andes. We would like to acknowledge the Department of Chemical Engineering for providing access to the TGA instrument and the Human Genetics Lab at Universidad de los Andes for kindly donating the E. coli strain used in this work. Finally, we would like to thank the Microscopy Core Facility at Universidad de los Andes for access to the instruments and technical support with the confocal microscope.

\section{Disclosure}

The authors report no conflicts of interest in this work.

\section{References}

1. Komin A, Russell LM, Hristova KA, Searson PC. Peptide-based strategies for enhanced cell uptake, transcellular transport, and circulation: mechanisms and challenges. Adv Drug Deliv Rev. 2017;110-111:52-64

2. Uyterhoeven ET, Butler CH, Ko D, Elmore DE. Investigating the nucleic acid interactions and antimicrobial mechanism of buforin II. FEBS Lett 2008;582(12):1715-1718

3. Park CB, Yi KS, Matsuzaki K, Kim MS, Kim SC. Structure-activity analysis of buforin II, a histone $\mathrm{H} 2 \mathrm{~A}$-derived antimicrobial peptide: the proline hinge is responsible for the cell-penetrating ability of buforin II. Proc Natl Acad Sci U S A. 2000;97(15):8245-8250.

4. Muñoz-Camargo C, Salazar V, Barrero-Guevara L, et al. Unveiling the Multifaceted Mechanisms of Antibacterial Activity of Buforin II and Frenatin 2.3S Peptides from Skin Micro-Organs of the Orinoco Lime Treefrog (Sphaenorhynchus lacteus). Int J Mol Sci. 2018;19(8).

5. Cho JH, Sung BH, Kim SC. Buforins: histone H2A-derived antimicrobial peptides from toad stomach. Biochim Biophys Acta. 2009;1788(8): 1564-1569.

6. Afacan NJ, Yeung AT, Pena OM, Hancock RE. Therapeutic potential of host defense peptides in antibiotic-resistant infections. Curr Pharm Des. 2012;18(6):807-819.

7. Alves D, Olívia Pereira M. Mini-review: antimicrobial peptides and enzymes as promising candidates to functionalize biomaterial surfaces. Biofouling. 2014;30(4):483-499.

8. Zhang W, Shi X, Huang J, Zhang Y, Wu Z, Xian Y. Bacitracin-conjugated superparamagnetic iron oxide nanoparticles: synthesis, characterization and antibacterial activity. Chemphyschem. 2012;13(14):3388-3396.

9. Rodríguez-Luccioni HL, Latorre-Esteves M, Méndez-Vega J, et al. Enhanced reduction in cell viability by hyperthermia induced by magnetic nanoparticles. Int J Nanomedicine. 2011;6:373-380.

10. Creixell M, Bohórquez AC, Torres-Lugo M, Rinaldi C. EGFR-targeted magnetic nanoparticle heaters kill cancer cells without a perceptible temperature rise. ACS Nano. 2011;5(9):7124-7129.

11. Dilnawaz F, Sahoo SK. Therapeutic approaches of magnetic nanoparticles for the central nervous system. Drug Discov Today. 2015;20(10) $1256-1264$

12. Könczöl M, Ebeling S, Goldenberg E, et al. Cytotoxicity and genotoxicity of size-fractionated iron oxide (magnetite) in A549 human lung epithelial cells: role of ROS, JNK, and NF-кB. Chem Res Toxicol. 2011; 24(9): 1460-1475.

13. Arruebo M, Fernández-Pacheco R, Ibarra MR, Santamaría J. Magnetic nanoparticles for drug delivery. Nano Today. 2007;2(3):22-32.

14. Can K, Ozmen M, Ersoz M. Immobilization of albumin on aminosilane modified superparamagnetic magnetite nanoparticles and its characterization. Colloids Surf B Biointerfaces. 2009;71(1):154-159.

15. Bordbar AK, Rastegari AA, Amiri R, Ranjbakhsh E, Abbasi M, Khosropour AR. Characterization of modified magnetite nanoparticles for albumin immobilization. Biotechnol Res Int. 2014;2014:705068.

16. Wang G, Li X, Wang Z. APD3: the antimicrobial peptide database as a tool for research and education. Nucleic Acids Res. 2016;44(D1): D1087-D1093.

17. Valenzuela R, Fuentes MC, Parra C, et al. Influence of stirring velocity on the synthesis of magnetite nanoparticles (Fe3O4) by the co-precipitation method. J Alloys Compd. 2009;488(1):227-231.

18. Wen X, Yang J, He B, Gu Z. Preparation of monodisperse magnetite nanoparticles under mild conditions. Curr Appl Phys. 2008;8(5): 535-541.

19. Yamaura M, Camilo RL, Sampaio LC, Macêdo MA, Nakamura M, Toma HE. Preparation and characterization of (3-aminopropyl) triethoxysilane-coated magnetite nanoparticles. J Magn Magn Mater. 2004;279(2-3):210-217. 
20. Sadighian S, Rostamizadeh K, Hosseini-Monfared H, Hamidi M. Doxorubicin-conjugated core-shell magnetite nanoparticles as dual-targeting carriers for anticancer drug delivery. Colloids Surf B Biointerfaces. 2014;117:406-413.

21. Guruprasad K, Reddy BV, Pandit MW. Correlation between stability of a protein and its dipeptide composition: a novel approach for predicting in vivo stability of a protein from its primary sequence. Protein Eng. 1990. Available from: http://www.ncbi.nlm.nih.gov/pubmed/2075190. Accessed March 27, 2018.
22. Varshavsky A. The N-end rule pathway of protein degradation. Genes Cells. 1997;2(1):13-28. Available from: http://www.ncbi.nlm.nih.gov/ pubmed/9112437. Accessed September 10, 2018.

23. Park CB, Kim HS, Kim SC. Mechanism of action of the antimicrobial peptide buforin II: buforin II kills microorganisms by penetrating the cell membrane and inhibiting cellular functions. Biochem Biophys Res Commun. 1998;244(1):253-257.

\section{Publish your work in this journal}

The International Journal of Nanomedicine is an international, peerreviewed journal focusing on the application of nanotechnology in diagnostics, therapeutics, and drug delivery systems throughout the biomedical field. This journal is indexed on PubMed Central, MedLine, CAS, SciSearch $®$, Current Contents ${ }^{\circledR} /$ Clinical Medicine,
Journal Citation Reports/Science Edition, EMBase, Scopus and the Elsevier Bibliographic databases. The manuscript management system is completely online and includes a very quick and fair peer-review system, which is all easy to use. Visit http://www.dovepress.com/ testimonials.php to read real quotes from published authors. 